\title{
第28回北関東胸部疾患研究会抄録集
}

\section{〈一般演題 I 〉}

座長 : 小野 昭浩 (群馬大院・医・病態制御内科学)

1.レジオネラ肺炎罹患後に消化管出血を来した 1 例

$\begin{array}{lrrr}\text { 井上 } & \text { 照基, 加藤 } & \text { 真理, 柳澤 } & \text { 正敏 } \\ \text { 林 } & \text { 学, 前田 } & \text { 正毅, 根岸 } & \text { 哲夫 } \\ \text { 飯塚 } & \text { 光, 本間 } & \text { 学, 桑原 } & \text { 英眞 }\end{array}$

(国立病院機構沼田病院 内科)

レジオネラ肺炎は，ブドウ糖非醱酵の好気性グラム陰 性桿菌を含むエアロゾルを経気道的に吸入することによ り発症する感染症である. 合併症として中枢神経症状や 消化器症状を認めることがあるが, 今回我久はレジオネ ラ肺炎罹患後に消化管出血を来した 1 例を経験したので 報告する. 症例は 49 歳男性, $40^{\circ} \mathrm{C}$ 近い発熱が出現したた め近医を受診し，内服薬を処方されたが改善せず，精査 加療目的に当院紹介入院となった，既往歴では糖尿病， 高血圧, 高脂血症があり，内服加療中であった. 職業は浄 水場に勤務していた. 入院時検查所見では, WBC 13300/ $\mu 1, \mathrm{CRP} 25.9 \mathrm{mg} / \mathrm{dl}$ と高值であり, 尿中レジオネラ抗原 陽性, 喀痰培養より legionella pneumophila group 1 が検 出されレジオネラ肺炎と診断した。抗生物質による治 療を行い症状は改善し, 退院となった。退院 8 日後に, 労 作時息切れ, タール便を主訴に来院し, $\mathrm{Hb} 5.5 \mathrm{mg} / \mathrm{dl}$ と高 度の貧血を認めたため再入院となった，原因精查を行っ たが臨床像に合致する出血源は認めず，出血および急性 冠症候群による low output syndromeのため死亡した。 病理解剖では十二指腸の炎症, 潰瘍形成を認めたが, 局 所よりレジオネラ菌を検出することはできなかった。 レ ジオネラ肺炎と消化管出血は現時点では関連不明なが ら, 肺炎軽快後も合併症に十分注意し, 厳重な経過観察 が必要であると考えられた。

\author{
会 長: 青木 秀夫 (下仁田厚生病院) \\ とき:平成 19 年 6 月 23 日 (土) 午後 3 時 6 時 \\ ところ：マーキュリーホテル (前橋市大友町 3-24-1)
}

2. 胸水, 心囊液, 腹水貯留が診断の手がかりとなった SLE の 1 例

矢崎 淳, 鶴巻 寛朗, 山下 均
飯島 浩宣, 遠藤 克明, 丸田 栄
（桐生厚生総合病院 内科）
小畑 敬子, 植木 嘉衛

(東邦病院 腎臓内科)

SLE は特徵的な皮疹, 腎機能障害, 神経障害, 血液異常 などを特徵とする疾患である. 今回我々は, 感染を契機 にして発症し, 胸水, 心囊液, 腹水貯留が SLE 診断の手が かりとなった 1 例を経験したため, 若干の文献的な考察 を加えて報告する。

【患 者】 16 歳 女性【現病歴】受診 5 日前より両 手背の腫脹を認め, 四肢の筋力低下を認めた. 3 日前より 咳と痰が出るようになり，手が震えるようになった。こ の頃より $38^{\circ} \mathrm{C}$ 台の発熱を認め, 2007 年 4 月上旬に当院 内科外来受診. CPK の著明な上昇及び尿蛋白を認めたた め, 精查・加療目的にて同日入院とした，【既往歴】 14 歳：シンナー中毒 【家族歴】特記事項なし【輸血歴】 なし【アレルギー歴】特記事項なし【嗜 好】飲 酒：なし, 喫煙: 20 本/day $\times 4$ 年【検査結果】 $\mathrm{CH} 50$ $26 \mathrm{U} / \mathrm{ml}, \mathrm{C} 343 \mathrm{mg} / \mathrm{dl}, \mathrm{C} 48.6 \mathrm{mg} / \mathrm{dl}$, 抗核抗体価 2560 倍 (+) (speckled type), 抗 dsDNA 抗体 $54 \mathrm{IU} / \mathrm{ml}(+)$, 抗 $n R N P$ 抗体 $(+)$, 胸水中抗核抗体価 2560 倍 【画 像】 胸部 Xp にて左 CP アングル dull であり, CTR 57\% と心 拡大を認めた. 胸腹部 CT で心囊液・胸水貯留抢よび腹水 貯留を認めた.【経 過】SBT/ABPC, MINO 投与で 炎症反応の改善は認めたが，心囊液と胸水の増量を認め た. 臨床所見より診断基準を満たしたためSLEと診断 し, PSL30mg/body の投与を開始したところ, 心囊液と 胸水の改善を認めた。【考 察】文献的にはSLE の 16 〜 44\%に胸水貯留, 19〜50\%に心囊液貯留を認めたと報 告されている。.また，SLEに扔いて胸水中抗核抗体価は 160 倍以上であることが多く, 抗核抗体の胸水/血清比は 1 以上であると報告されている.【結 語】一般に若年 者で, 胸水・心囊液・腹水貯留を認婸合には, SLE も 鑑別疾患として検討する必要があると考えられた。また， 
胸水中の抗核抗体価もSLE 診断の一助になると考えら れた。

3. 胸部 CT scan にて典型的な crazy paving pattern を 呈した器質化肺炎の 1 例

小柏 剛, 増㴊 健, 石塚 隆雄
飯塚 邦彦, 梅枝 愛郎

（富岡総合病院 内科）

前原 康延

(同 画像診療科)

本間 学

(同 病理)

【症 例】 74 歳 男性【主 訴】右下肺野胸部異常

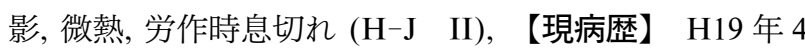
月 18 日頃より頻脈 (安静時 80 程度)を認めるように なった. その後, 37 度台程度の微熱と労作時息切れ感じ るようになった，最近になり，咳嗽，喀痰を認め，近医を 受診. 胸部 Xp にて胸部異常陰影を指摘され当院紹介受 診となった。胸部 CT にて【既往歴】無菌性髄膜炎 (H6 年), HT (60 歳ごろから内服：Nifedipine), 蓄膿症 $(-)$, 喘息 $(-)$, 花粉症 $(+, 2-3$ 月, 20 年まえから) 【生 活歴・嗜好歴】喫煙歴なし. 教職 37 年. 機会飲酒. 粉鹿 吸入歴なし.ペット $($ 一). 健診での指摘これまでない. 羽 毛布団使用【入院時現症】 $\mathrm{Ht}=169 \mathrm{~cm}, \quad \mathrm{BW}=65.2 \mathrm{~kg}$, $\mathrm{BMI}=22.8, \quad \mathrm{BP}=129 / 90, \quad \mathrm{PR}=96, \quad \mathrm{SpO} 2=94 \%, \quad \mathrm{BT}=$ $37.1^{\circ} \mathrm{C}$, 鎖骨上窩の陥凹 $(-)$, 吸気時の頸静脈虚脱 $(-)$, short neck $(-)$, development of M. sternocleidmastoideus $(+)$, 胸部 : fine crackle $(+)$, clubbed finger $(-)$, S1 $(\rightarrow)$ S2 $(\rightarrow)$ S3 $(-)$ S4 $(-)$, no murmur, 腹部: 平坦軟, 肝脾 触知せず, 四肢：clubbed finger (一)【入院時検査所見】 WBC 6400/ $\mu 1, \mathrm{Hb} 13.6 \mathrm{~g} / \mathrm{dl}$, Plt 28.4 万/ $\mu 1$, AST 20IU/1, ALT $13 \mathrm{IU} / 1, \quad$ LDH $216 \mathrm{IU} / \mu 1, \quad$ CRP $3.0 \mathrm{mg} / \mathrm{dl}, \quad$ ESR $60 \mathrm{~mm} / \mathrm{hr}$, CEA $1.1 \mathrm{ng} / \mathrm{ml}, \mathrm{KL}-6413 \mathrm{U} / \mathrm{ml}$ と炎症反応の 上昇以外に特記すべき所見はなく，血液ガス分析では Room air下で pH 7.439, $\mathrm{PaCO} 239.7$ Torr, $\mathrm{PaO} 276.5$ Torr であり, A-DO2=23.9 と開大を認めた。また，呼吸 機能検査においては, \%VC 77.37, FEV1.0\% 73.16 と拘 束性換気障害を認めた。【胸部 C T 】気管支血管束の 肥厚と crazy paving patternを認めた. 【入院後経過】 びまん性肺疾患の鑑別として, 肺胞蛋白症, 膠原病及び 関連疾患薬剂誘起性肺疾患, 肺胞上皮癌等を鑑別として, 気管支鏡検查, 肺胞洗浄目的に入院となった. BALFで は無色透明の洗浄液のみであった，細胞分画では細胞数 $3.0 \times 10 * 5 / \mathrm{ml}$, リンパ球 $75 \%$ の著增と, 好酸球 $14 \%$ の増加を認めた. TBLBでは organizing pneumonia patternであり, 肺胞蛋白症, 悪性腫瘍は否定的であった. 薬 凨性肺障害は完全に否定できず，降圧剤を変更とした， その後, 胸部単純 Xp にて下肺野の器質化の増悪が認め られ, ステロイドパルス目的に入院. 治療後は, 画像所見
でも改善傾向を認め，退院後は外来にて経過観察となっ た.

4. Flexible bronchofiberscope を用いた胸腔鏡検査が診 断に有用であった 2 例

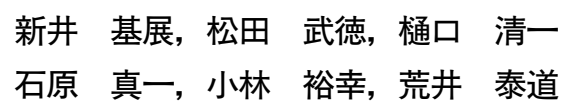

（伊勢崎市民病院 内科）

鈴木 豊 (同 病理部)

【目 的】胸水の分析や画像所見からはその原因が特定 できなかった胸膜炎症例に対し，軟性気管支鏡を用いて 胸腔鏡検查を行い，その有用性を検討した。【対象と方 法】 2006 年 3 月から 2007 年 5 月の期間に胸水貯留を 認め, 胸水分析により病理学, 細菌学的に診断が得られ なかった 8 例に局所麻酔下で胸腔鏡検查を行った. 6 例 は片側性に胸水を認め, 2 例は両側性に胸水を認めた. 片 側性胸水のうち原発性肺癌が 1 例, 結核性胸膜炎が 1 例 診断された？その他の 4 例は非特異的な胸腔鏡所見しか 得られず, うち 3 例は臨床的にも非特異的胸膜炎と診断 された. 両側性胸水を認めた 2 例はいずれも胸腔鏡で異 常所見を認めなかったが後の経過で膠原病と診断され た.【結 論】本法は悪性腫腸や結核に対しては検出 能力が高く, 有用な検查と考元られる. また, 両側性に胸 水を認めた際には膠原病を鑑別に挙げる必要があると思 われる。

\section{〈一般演題 II〉}

座長：解良 恭一 (群馬大院・医・病態制御内科学)

\section{5。髄膜播種をきたした原発不明縦隔リンパ節腺癌の一} 例

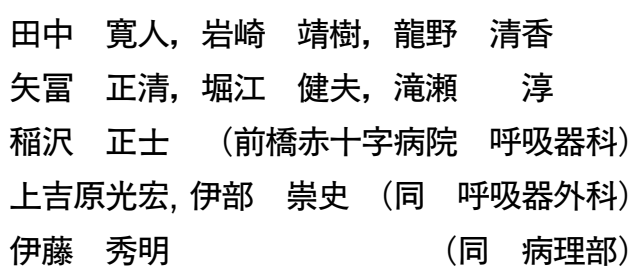

症例は 62 歳 の男性. 2006 年 4 月上旬より胸痛出現す るも心電図, 胸部 X 線にて明らかな異常なく経過観察さ れていた，その後も胸痛改善なく, 増悪を認めたため 6 月下旬, 胸部 CT を施行し, 上縦隔に腫瘤影を認めたため 7 月上旬に当院紹介ののち, 外科的上縦隔腫瘤生検目的 に当院呼吸器外科入院となった. 入院時の採血で腫瘍 マーカーは CEA $46.1 \mathrm{ng} / \mathrm{ml}, \mathrm{CA} 19-9178.0 \mathrm{U} / \mathrm{ml}$ と上昇 を認めた。胸部 CT では大動脈弓部周囲から左鎖骨下動 脈周囲の緹隔に不整形で境界が不明膫な軟部濃度域の腫 瘤性病変を認めた。 縦隔腫瘍生検を施行し, HE 染色で細 
胞質内に粘液空胞を伴う腫瘍細胞が小乳頭状集塊ないし 索状胞巣を形成し間質の線維化を伴って浸潤, 増殖する 腺癌と診断された，免疫染色にて TTF-1 陰性，CK7 陽 性, CK20 陰性であった. 画像的には縦隔以外に原発と思 われる病変は認めず, 原発不明縦隔リンパ節腺癌として 治療法の選択に苦慮したが画像及び病理所見等を再検討 し, 肺癌の可能性が否定できないと判断し, CDDP $\left(80 \mathrm{mg} / \mathrm{m}^{2}\right.$, day 1$)+\mathrm{VNR}\left(20 \mathrm{mg} / \mathrm{m}^{2}\right.$, day 1,8$)(1$ cycle $)+$ concurrent RT (60Gy/30fr) にて化学放射線併用療法を 行った. 化学療法 1 サイクル終了後, 腎機能障害のため 2 サイクル目は施行できなかった. 化学療法 1 サイクルお よび放射線療法後の効果判定は SD であった。経過中に 左下肢のしびれを訴えたため腰椎 MRI を施行し, 馬尾 に多数の造影される結節性病変を認めた。 また, 脳 MRI にて左内耳道内に造影効果を示す腫瘤を認めた.1ケ月 後の MRI では馬尾の結節性病変は増大傾向を認めたた め, 髄膜播種を疑い腰椎穿刺を行い, 髄液細胞診にてク ラス $\mathrm{V}$, 腺癌と診断された. その後, 左下肢のしびれに加 え排便・排尿障害が出現したため, 病状コントロール目 的に腰髄に対して姑息的に total 30Gy 照射を行ったが, 明らかな症状の改善はみられなかった. 全身状態は徐久 に悪化し永眠された．報告では，原発不明癌の頻度は全 癌の $0.5 \sim 6.7 \%$ とされている. 本症例で認められた髄内 転移は, 癌患者の剖検例の $1 \sim 3 \%$ そ れな疾患で, 原 発巣は肺癌と乳癌が多いとされている. 原発不明癌で髄 膜播種を認めた症例は本邦では報告がなく, 稀な症例を 経験したので報告した。

\section{6. 肺癌治療中に間質性肺炎の急性増悪を来した 2 例 秋山 真人, 多胡 洋子, 財 裕明 吉田 誠, 正田 純史, 堀越 勤 青木 秀夫 （下仁田厚生病院 内科） 小林 節雄 (上牧温泉病院)}

【症例 1】79 歳男性. H17.8月に健診にて胸部異常陰影 を指摘され当科受診. 画像所見より左下葉腫瘍, 間質性 肺炎, と診断. 西群馬病院を紹介, 左肺癌を診断, 同年 11/ 24 同院外科にて左下葉切除, 舌区部分切除 ND1a 施行さ れた. その後, H18. 縦隔及び右鎖上リンパ節再発にて放 射線治療施行された. 8/18〜10/06 右肺門, 縦隔に 66Gy, 右鎖上に $60 \mathrm{~Gy}$. 同年 11 月に入り，労作時息切れ増強し， 来院. 画像上両側性に非区域性に, 中葉, 舌区, 下葉に線 状網状陰影や淡い斑状陰影を認めた. 非定型肺炎も鑑別 しつつ, CTM+MINO 併用しながら，ステロイドパルス 治療施行したが, 奏効せず, 死亡された. 放射線肺炎の危 険因子として, (1)被曝量に比例して発症する. (2) 40Gy 以 上ではほぼ必発. (3)肺に基礎疾患 (COPD, 塵肺, 陳旧性 肺結核, 間質性肺炎〜肺線維症) などが一般的に知られ
ている. 【症例 2】78 歳男性. 当院循環器内科定期経 過観察中, H16.9 月に胸部異常陰影を指摘された. 左上葉 に腫瘍陰影認め精査勧めるも, 放置. その後, 徐々に腫瘍 増大した. H18, 西群馬病院入院, 非小細胞性肺癌 cT4N2M0 と診断された. 癌の進展したステージ, 基礎疾 患として肺線維症などより best supportive care にての 経過観察となっていた. その後, 患者自ら新たな治療法 を求め横浜市某クリニック受診. 諸検査の結果, H19.2 月 下旬より, 本邦未認可である EGFR-TK 阻害剤 erlotinib の治療を試みた。一日 1T 隔日服薬で, 5T 内服した時点 で, 動悸, 息切れ増強し来院. 胸部 Xp にて両側性びまん 性に陰影を認めた. ARDS にて, NPPVによる呼吸管理, 抗生剂併用の下ステロイドパルス治療施行した. が, 奏 効せず, 死亡された. Erlotinibによる間質性肺炎が強く 疑われた. 本邦認可 EGFR-TK 阻害剤ゲフィチニブに関 する急性肺障害, 間質性肺炎 ILD 危険因子として(1)喫煙 歴あり(2)既存の間質性肺炎(3)非小細胞性肺癌初回診断か ら ILD 発症までの期間が 6r月以内(4) PS 不良 (2 以上) (5)正常肺占有率 (CT 画像による) が低いこと (50\%以下) (6)年齢 (55 歳以上) (7)心血管系合併症を呈していること があげられている．本例は，ゲフィチニブではないが， EGFR-TK 阻害剂で同様な危険因子が考えられる.【結 語】放射線照射療法及び EGFR-TK 阻害剤による肺癌 治療中, 間質性肺炎の致死的急性増悪を来した 2 例を経 験した. 肺癌治療における放射線療法や化学療法に際し, 既存の間質性肺疾患, 特に, 特発性肺線維症は急性肺障 害・ILDの発症及び予後重篤化の極めて重要なリスク ファクターであり,これら治療法の選択には特に慎重を 期す必要性を改めて認識させられた。

\section{7. 肺癌術後に多発骨格筋転移にて再発した 1 例 鈴木 邦明, 富澤 由雄, 上出 庸介 山田 秀典, 小林 剛, 吉井 明弘 佐藤 浩二, 渡辺 覚, 斎藤 龍生 (国立病院機構西群馬病院 呼吸器科)}

症例は 50 代, 男性. 主訴は䅡部痛. 2006 年 1 月に検診 にて胸部異常陰影を指摘されて当院に紹介入院となっ た. 精査にて原発性肺癌の診断となり, 同年 2 月に当院 呼吸器外科にて右肺全摘十心膜部分合併切除術を行っ た. 術後病理組織は中分化加ら低分化型腺癌, pT2N1M0Stage II B であった. 術後補助化学療法としてカルボプ ラチンとゲムシタビンの併用療法を計 4 コース行い, 外 来にて経過観察されていた. 2006 年 12 月より左後頚部, 左大腿部にしこりが出現, 2 月頃より痛みが出現した. MRI にて左後頝部と左大腿部の筋肉内に腫瘤を認めた ため, 4 月に群馬大学医学部附属病院整形外科にて試験 切除術を行い, 病理組織検查にて肺癌の筋肉転移と診断 
された. 術後より頝部痛が増強してきたため, 精查加療 目的に当院へ入院となった，全身検索を行った結果， cTxN0M1 (左大腿部筋肉, 左後頝部筋肉, 脳) -Stage IVの 診断となった. 頝部痛が強くPS3 と全身状態不良のため, 化学療法の適応はなかった. 疼痛コントロール目的に後 䅡部に放射線照射を計 $49.5 \mathrm{~Gy}$ 行い, 頝部痛は軽減され, 現在は左大腿部に対して放射線照射を行っている．原発 性肺癌の筋肉転移は非常に稀であり, 貴重な症例と思わ れ, 若干の考察を含めて報告する.

\section{8. 急速に増大した悪性胸膜中皮腫の 1 例}

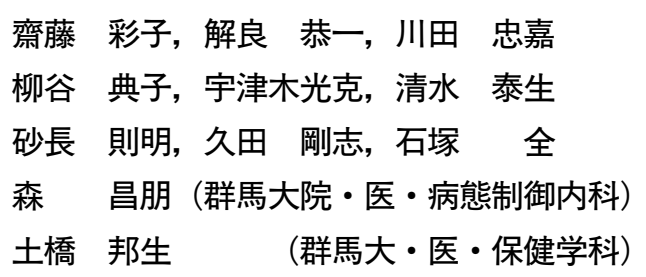

【症 例】 67 歳, 男性で, 4 日間の労作時息切れを主訴 に近医受診. 胸部 XP にて右胸水貯留を認めたため, 平成 18 年 8 月 15 日, 当院紹介入院となった. 身体所見は異常 なく, 検査所見は白血球, CRP の軽度上昇を認めるのみ であった. 入院後, 胸部ドレナージが施行され, 浸出性胸 水 $3000 \mathrm{ml}$ を認めた. 胸部 CT は\# 3p リンパ節腫大と右 胸膜の軽度肥厚を認めた。胸水細胞診は腺癌の所見を認 め, この段階で肺癌が疑われたが, 8 月 21 日の胸部 CT では右胸膜肥厚が増大した，患者の状態は急速に悪化し，
8 月 24 日の胸部 CT では, 右胸膜が全周性に肥厚し, 8 月 28 日, 腫瘍の増大により死亡された。家族の同意により 病理解剖が施行され, 肉眼的には, 右胸膜が $1 \mathrm{~cm}$ 程, 全周 性に肥厚していた，組織学的には, 悪性胸膜中皮腫の所 見を示し, 免疫染色にても, カルレチニン, WT-1 が陽性, CEA, TTF-1, Ber-EP4 が陰性であり, 悪性胸膜中皮腫の 診断がなされた。

悪性胸膜中皮腫は, 最近, 増加している予後不良の疾 患である. 症状の出現から死亡まで3ヶ月以内との報告 もある. 急速な増大のため, 症状出現から 3 週間以内に 死亡した報告や突然死にて悪性胸膜中皮腫の診断がなさ れた稀な報告もある。本例も症状出現から 2 週間程度で あり, 生前, 診断することができなかった. 悪性胸膜中皮 腫が急速に増大する要因については明らかではないが, 本例は貴重な症例と考えるので報告する

\section{〈教育講演〉}

座長：青木＼cjkstart秀夫（下仁田厚生病院）

シックハウス症候群・化学物質過敏症一現状と展望

坂部 貢 先生

(北里大学薬学部・公衆衛生学 教授 北里研究所病院・臨床環境医学センター

センター長) 